\title{
Caries Risk Assessment in Students With Disabilities
}

\author{
Alfini Octavia ${ }^{1, *}$ Trinita Lydianna ${ }^{2}$ DessyAudira $^{3}$ Chairunnisa Istiqomah ${ }^{4}$
}

\begin{abstract}
${ }^{1}$ Pediatric Dentistry Department, the School of Dentistry Universitas Muhammadiyah Yogyakarta, Yogyakarta, Indonesia ${ }^{2}$ Pediatric Dentistry Department, the School of Dentistry Universitas Muhammadiyah Yogyakarta, Yogyakarta, Indonesia ${ }^{3}$ Pediatric Dentistry Department, the School of Dentistry Universitas Muhammadiyah Yogyakarta, Yogyakarta, Indonesia ${ }^{4}$ Pediatric Dentistry Department, the School of Dentistry Universitas Muhammadiyah Yogyakarta, Yogyakarta, Indonesia *Corresponding author.Email: alfinioctavia@umy.ac.id
\end{abstract}

\begin{abstract}
Background. Dental caries is the sixth-highest health problem in Indonesia. This condition has a negative impact on the quality of life of people. Therefore, we need to reduce caries by identified the risk of caries. Most of the children with disabilities have a dependency on people surrounding them, including the process of cleaning their teeth and mouth that might lead to the possibility of having caries. Aims. The research aims to identify the caries risk of students with disabilities aged 6-12-year old in SLB Negeri 1 Bantul Yogyakarta.Methods. The method of this study is descriptive observational with a total sampling technique. This study population of this study was all students aged 6-20-year old, with a visual disability, hearing disability, and orthopedically disability in SLB Negeri 1 Bantul Yogyakarta. There are 54 students who are eligible according to the inclusion criteria. Caries risk is measured by the Caries Assessment Tool (CAT) released by The American Academy of Paediatric Dentistry (AAPD). Results. The results are 46 out of 54 students SLBN 1 Bantul have high caries risk (85\%), and two students have moderate caries risk (3,7\%), and six students have low caries risk (11\%). Conclusion It can be concluded that most of the students with disabilities in SLB Negeri 1 Bantul have a high risk of caries.
\end{abstract}

\section{Keyword: Caries risk, visual disability, hearing disability and orthopedically disability}

\section{INTRODUCTION}

Dental caries is the most common disease found in the oral cavity and lead to pain without appropriate treatment. Previous research showed that caries is the six highest disease that was suffered by people in Indonesia. The prevalence of caries in Indonesia is increased since 2007. The most age that affected is 12 years old and upper 65 years[1].

Dental caries has a broad impact on human quality of life. Therefore, it is necessary to reduce caries prevalence by identifying the individual risk of caries[2],[3]. The caries risk is the probability of the development of caries in a certain period. The age group of school students has a high risk of dental caries. This age group is between 6-12-year old that is a critical time because the deciduous teeth start to exfoliate, and the permanent teeth start to erupt. The teeth are susceptible to caries when first erupt in the mouth and easy to demineralize [4]. Children with disabilities are children that also have a high risk of caries due to their dependency on people surrounding in maintaining their oral health. Some studies revealed that children with visual, hearing, and orthopedically impairment are including children who have a high risk because of their limitation in tooth brushing and dependency on parents or caregivers [5]. However, some studies stated that caries in children with particular disabilities is not significant different compare to normal children[6].

Hearing is the key to the learning process in verbal communication during the cognitive development of the children. Good hearing makes the children deal with commands, and the voice comes from surrounding. Deaf children are the children who have limitations in hearing partially or totally [7].

The children with orthopedically handicapped have disorders in motor movement and the disturbance in function, such as bone, muscle, and joint. Some students also have restricted communication that affects the learning process [8].

Visual impairment could mean impairment to perceive objects and associate the conscious experience of the world to cognitive. It also lacks the visual guide movement and action brought by the motor system [9].

Because of their impairments, they depend on the other people surrounding them. The compromised ability might lead to a reduction in health-related quality of life.

The caries risk owned by an individual is varied and associated with the balance of trigger and inhibition factor. The instrument for measuring to identify the caries risk is caries risk assessment. In order to acknowledge the level of caries risk, this instrument might be applied to identify the caries risk level in the students with impairment in Sekolah Luar Biasa Negeri 1 Bantul (SLB N 1 Bantul)

Sekolah Luar Biasa Negeri 1 Bantul (SLB N 1 Bantul) is a special school that educates the students with impairments. The vision of this school is to educate the student with impairment in their limitation to achieve their functional and social life professionally. More over, most of 
the students of this school live in the residential around Bantul that have homogeneous characteristic. These characteristics become the reason to choice this school as the location of the study.

The objective of the study is to identify the caries risk of students with disabilities aged 6-20-year old in SLB Negeri 1 Bantul Yogyakarta.

\section{METHODS}

A descriptive observational study with a cross-sectional design was conducted in SLB N 1 Bantul during September 2018-February 2019. The population is all the student's age 6-20-year-old. The sampling method of this study is a total sampling. The recruitment of eligible subjects based on the inclusion criteria: 1. Have only one an impairment (hearing/vision/orthopedic) 2. Aged 6-12-year-old in January 20193 . Cooperative student 4. Parents fill the informed consent to join the study. The exclusion criteria are:1. Children with other physical disabilities 2. Have systemic disease 3. Consume systemic drug. Children who eligible as the subjects are 54 students.

The examination was conducted based on the Caries Risk Assessment that was established from the American Academy of Pediatric Dentistry (AAPD) that comprises of intraoral examination, saliva flow examination, and questionnaire for parents or caregiver. The oral examination included the persistence of caries, white spot lesion, the persistence/ condition of filling and the using of an intraoral appliance, and the condition of $\mathrm{pH}$-saliva [10]
Table 1. American Academy of Pediatric Dentistry Caries Risk Assessment Tool (CAT*)

\begin{tabular}{|c|c|c|c|}
\hline & Low risk & Moderate Risk & High Risk \\
\hline $\begin{array}{l}\text { Clinical } \\
\text { condition }\end{array}$ & 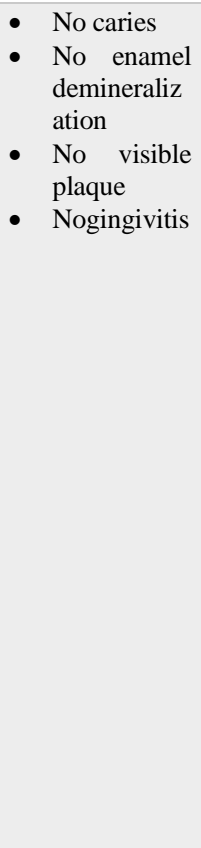 & $\begin{array}{l}\text { - Caries teeth in tl } \\
\text { past } 24 \text { months } \\
\text { - } 1 \text { area of enam } \\
\text { demineralization } \\
\text { - Caries"white sp } \\
\text { lesion. } \\
\text { - Gingivitis }\end{array}$ & $\begin{array}{l}\text { - Caries teeth } \\
\text { in the past } \\
12 \text { month } \\
\text { - More than } 1 \\
\text { area } \\
\text { demineraliz } \\
\text { ation } \\
\text { - Enamel } \\
\text { area, white } \\
\text { spot lesion } \\
\text { - Visible } \\
\text { plaque on } \\
\text { the anterior } \\
\text { front teeth } \\
\text { - Radiographi } \\
\text { c enamel } \\
\text { caries } \\
\text { - High titer of } \\
\text { Streptococc } \\
\text { us mutans } \\
\text { - Wearing a } \\
\text { dental or } \\
\text { orthodontic } \\
\text { appliance } \\
\text { - Enamel } \\
\text { hypoplasia }\end{array}$ \\
\hline $\begin{array}{l}\text { Environ- } \\
\text { mental } \\
\text { Characteris } \\
\text { ic }\end{array}$ & & $\begin{array}{l}\text { - Suboptim } \\
\text { al } \\
\text { systemic } \\
\text { fluoride } \\
\text { exposure } \\
\text { with } \\
\text { optimal } \\
\text { topical } \\
\text { exposure } \\
\text { - Occasion } \\
\text { al (1-2) } \\
\text { between } \\
\text { meal } \\
\text { exposure } \\
\text { to simple } \\
\text { sugar or } \\
\text { food } \\
\text { strongly } \\
\text { associate } \\
\text { d with } \\
\text { caries } \\
\text { - Mid-level } \\
\text { caregiver } \\
\text { socioecon } \\
\text { omic } \\
\text { status } \\
\text { - Irregular } \\
\text { use of } \\
\text { dental } \\
\text { service }\end{array}$ & $\begin{array}{l}\text { - Suboptimal } \\
\text { topical } \\
\text { fluoride } \\
\text { exposure } \\
\text { - Frequent } \\
\text { between- } \\
\text { meal } \\
\text { exposure to } \\
\text { simple } \\
\text { sugar or } \\
\text { food } \\
\text { strongly } \\
\text { associated } \\
\text { with caries } \\
\text { - Low-level } \\
\text { caregiver } \\
\text { socioecono } \\
\text { mic status } \\
\text { - No usual } \\
\text { source of } \\
\text { dental care } \\
\text { - Active } \\
\text { caries } \\
\text { present in } \\
\text { mother }\end{array}$ \\
\hline
\end{tabular}

\section{RESULT}

The socio-demography status in table 2 shows the condition of the family and dental habits such as fluoride, dental visit, and meal preference. The mean age of hearing impairment $8.71 \pm 1.67$, visual impairment $14.7 \pm 4.89$, and orthopedically impairment $10.20 \pm 1.39$. In gender aspect, female children with hearing impairment are more (16 students) than male (10 students). On the contrary, male 
students in visual impairment are more than female. Students with orthopedic impairment have the same number both male and female ( 5 students)

Table 2. Age and gender characteristic of Subjects

\begin{tabular}{lccc}
\hline & Mean of age \pm SD & \multicolumn{2}{c}{ Gender } \\
\hline Hearing & $8.71 \pm 1.67$ & Male & Female \\
\hline Visual & $14.72 \pm 4.89$ & 10 & 16 \\
\hline Orthopedic & $10.20 \pm 1.39$ & 12 & 6 \\
\hline
\end{tabular}

Most of the students come from low-income families. However, they regularly do teeth brushing with fluoride. The habit of consuming high sugar intake relatively low, and the dentist visit experiences are less than $54 \%$ of students (Table 3)

Table 3. The risk factor of caries

\begin{tabular}{|c|c|c|c|}
\hline Variable & $\begin{array}{l}\text { Hearing } \\
\mathrm{N}(\%)\end{array}$ & $\begin{array}{l}\text { Visual } \\
\mathrm{N}(\%)\end{array}$ & $\begin{array}{l}\text { Orthopedic } \\
\mathrm{N}(\%)\end{array}$ \\
\hline \multicolumn{4}{|l|}{ Economy background } \\
\hline - $\quad$ Low income & $25(96 \%)$ & $15(83 \%)$ & $9(90 \%)$ \\
\hline - High income & $1(0.04 \%)$ & $3(16 \%)$ & $1(10 \%)$ \\
\hline $\begin{array}{l}\text { Consume snack with sugar } \\
\text { ingredients every day }\end{array}$ & $9(34 \%)$ & $4(23 \%)$ & $3(27 \%)$ \\
\hline Use of fluoride tooth paste & $26(100 \%)$ & $17(100 \%)$ & $10(100 \%)$ \\
\hline Ever Visit dentist before study & $11(42 \%)$ & $5(29 \%)$ & $6(54 \%)$ \\
\hline
\end{tabular}

In table 4, most students in all impairment have a high risk of caries over $70 \%$, respectively. The highest is in orthopedically impairment $(90.9 \%)$, hearing impairment $(88.5 \%)$, and visual impairment $(76 \%)$.

Table 4. Caries Risk assessment among the children with impairments

\begin{tabular}{cccc}
\hline Caries risk & $\begin{array}{c}\text { Hearing } \\
(\%)\end{array}$ & $\begin{array}{c}\text { Visual } \\
(\%)\end{array}$ & $\begin{array}{c}\text { Orthopedic } \\
(\%)\end{array}$ \\
\hline Low & 7.7 & 17.6 & 9.1 \\
Moderate & 3.8 & 5.8 & 0 \\
High & 88.5 & 76.4 & 90.9
\end{tabular}

\section{DISCUSSION}

The caries risk assessment has an objection to reducing the caries occurrence by preventing the risk factor. Angela stated that the caries risk assessment is a method to evaluate the oral health of children. Therefore, dentists could conduct preventive treatment [11].

The level of caries risk is determined based on the AAPD form given to parents as a questionnaire. The high- risk caries level revealed if the student has more than one lesions in a tooth, has a white spot lesion, and has a low saliva flow [12].

The examination showed that the risk caries level in children with impairments, especially children with orthopedically impairment in SLB Negeri 1 Bantul mostly is high $(90.9 \%)$. Only 1 out of 11 students who have lowrisk caries level (9.1\%). A previous study in Manado, Indonesia, stated that the DMF-T score of children with orthopedically handicapped is high. This condition has a correlation that the high risk of caries might lead to a high DMF-T score

Disability factors in motoric and dependency on others when doing their life care bring the consequence of the high risk of caries level [13]. Children who have disabilities in motoric sometimes have difficulty in open-closed mouth, chewing, and lowly gagging reflex. Therefore, the time of food-pick is getting longer than normal children. Besides, they have a problem in the coordination of neuro-muscular in the function of chewing and swallowing [14]

The results of the study showed that high caries risk level to the deaf children in SLB N 1 Bantul Yogyakarta as much as 88,5\%. Koch and Poulsen (2017) stated that deaf children have higher caries risk than normal children due to their disability in receiving the information and understanding the education of dental health [15]. In most cases, it is necessary to find good communication to prevent inappropriate understanding or dental behavior that might influence oral health. There are many kinds of form communication for deaf or hearing impairment, such as hearing aids, induction loops and infrared systems and, telephone communication, Text-phones, and Typetalk systems [16].

Caries risk level to children with visual impairment is high $(76.4 \%)$ in this study. It is confirmed to a previous study that revealed the same results. The reasons might be caused by the inability to remove the plaque, and lack of supervision while do the tooth brushing activity and lack of self-help skills [17],[18].

\section{CONCLUSION}

Most students with disabilities in SLB Negeri 1 Bantul have a high risk of caries. Most students with disabilities in SLB Negeri 1 Bantul have a high risk of caries. The factors that might influence the level of caries risk are biology factor e.g., the bacteria involved, ph saliva and daily dental health habit.

\section{ACKNOWLEDGMENT}

We would like to thank to stakeholders of SLBN 1 Bantul, children, and their parents for giving us access to conduct this study. We also like to acknowledge the help and contribution of the doctors and other assisting staff. 


\section{REFERENCES}

[1] Kementerian Kesehatan Republik Indonesia, "Riskesdes 2018," 2018.

[2] J. Jokela and P. Alanen, "Risk-based early prevention in comparison with routine prevention of dental caries: a 7-year follow-up of a controlled clinical trial; clinical and economic aspects," vol. 7, pp. 1-7, 2005.

[3] S. U. Maheswari, J. Raja, A. Kumar, and R. G. Seelan, "Caries management by risk assessment: A review on current strategies for caries prevention and management," J. Pharm. Bioallied Sci., vol. 7, no. Suppl 2, pp. S320-S324, Aug. 2015.

[4] N. B. Pitts, D. T. Zero, P. D. Marsh, K. Ekstrand, and J. A. Weintraub, "Dental caries," no. May, 2017.

[5] Z. Al-Qahtani and A. H. Wyne, "Caries experience and oral hygiene status of blind, deaf and mentally retarded female children in Riyadh, Saudi Arabia.," Odontostomatol. Trop., vol. 27, no. 105, pp. 37-40, Mar. 2004.

[6] M. R. H. Khan, M. Ahmad, M. M. Islam, S. Ahmed, M. R. A. Prodhan, and - Sharminakter, "Oral health status of disabled children attending special schools of Dhaka city," Updat. Dent. Coll. J., vol. 9, no. 2, pp. 32-35, 2019.

[7] M. L. Hawley, R. Y. Litovsky, and J. F. Culling, "The benefit of binaural hearing in a cocktail party: Effect of location and type of interferer," J. Acoust. Soc. Am., vol. 115, no. 2, pp. 833-843, 2004.

[8] K. . Heller and S. Jonnes, Dawn, "Supporting the Educational Need Student with Orthopedic impairment," Phys. Disabil. Educ. Relat. Serv., pp. 3-24, 2003.

[9] A. D. Milner, "The Visual Brain in Action The Visual Brain in Action,” no. May, 2014.

[10] American Academy of Pediatric Dentistry, "Cariesrisk assessment and management for infants, children, and adolescents," Pediatr. Dent., vol. 40, no. 6, pp. 205-212, 2018.

[11] F. R. Gomez, L. Angeles, Y. Crystal, M. W. Ng, J. Crall, and L. Angeles, "Pediatric Dental Care: Prevention and Management Protocols Based on Caries Risk Assessment," no. October, 2010.
[12] J. Marshall, S. Barbara, and L. Mancl, "Caries Risk assessment and caries status of children with autism," Pediatr. Dent., vol. 32, no. number 1, p. 69-75(7), 2010.

[13] R. Welbury and M. Duggal, Paediatric Dentistry, Third Edit. Oxford University Press, 2005.

[14] L. Van Den Engel-hoek, I. J. M. De Groot, B. J. M. De Swart, and C. E. Erasmus, "Feeding and Swallowing Disorders in Pediatric Neuromuscular Diseases: An Overview AND SWALLOWING DISORDERS," vol. 2, pp. 357-369, 2015.

[15] G. Koch, S. Poulsen, I. Espelid, and D. Haubek, Pediatric Dentistry: Clinical Approach, Third Edit. Copenhagen: BlackWell Publishing Ltd, 2017.

[16] S. San, B. Alsmark, J. D. N. García, M. Rosa, M. Martínez, N. Esther, and G. López, "How to improve communication with deaf children in the dental clinic How to improve communication with deaf children in the dental clinic," Med Oral Patol Oral Cir Bucal., vol. 12(8), no. May, pp. 76-81, 2018.

[17] L. Doichinova, "Risk Assessment for the Development of Caries in Visually Impaired Children in Sofia City, Bulgaria," Int. J. Sci. Res., vol. 4, no. 2, pp. 1108-1111, 2015.

[18] K. Reddy and A. Sharma, "Prevalence of oral health status in visually impaired children YR - 2011/1/1," J. Indian Soc. Pedod. Prev. Dent., no. 1 ULhttp://www.jisppd.com/article.asp?issn=09704388 ; year $=2011$; volume $=29 ;$ issue $=1$; spage $=25$; ep age $=27$; aulast $=$ Reddy; $\mathrm{t}=5$, p. 25 OP-27 VO-29, 2011 